\title{
The Effect of Privatization on the Performance of Employees: A case study on Karachi Electric Supply Company
}

\author{
Malik Dad*
}

\begin{abstract}
The objective of this research was to investigate the effects of privatization on the employee performance of Karachi Electric Supply Company (K.E.S.C) and find out the changes in the overall employee performance. For this purpose, research was conducted from the employees of K.E.S.C. The variables identified through the literature review were commitment, organizational change, communication, training and development, financial benefits, and job security. The research aimed at finding out what changes have been taken place in these factors after privatization and what were the impacts of those changes on the overall performance of the employees. In order to investigate the variables, a detailed study was carried out. Both; employees' and employers' perspectives regarding the performance changes were investigated. For this purpose, employees belonging to the middle-level management of K.E.S.C. working at IBC's since the pre-privatization era was chosen, as the major change was implemented in these units of K.E.S.C. primarily. Apart from surveys, 3 interviews of management working at integrated business units of K.E.S.C. were also conducted as they have direct interaction with the employees and played important role in managing and implementing change. The results of the study revealed that change in the employees' performance was viewed by employees as positive and significant and supplement this point with extensive training and development programs, new performance management system, organizational restructuring, amplified remuneration package, enhanced communication and betterment of the working environment. Keeping in view the perspective of the management and the employees on the change after privatization, the research study concludes that though K.E.S.C's management carried out the change program in a proper and organized manner, by considering several critical factors for its successful implementation.
\end{abstract}

Keywords: Karachi electric supply company; variables identified; new business strategies; integrated business centers.

JEL Classification: $Z O O$

\section{INTRODUCTION}

\section{Background of the Study}

The topic of this research is "Effect of Privatization on Employee Performance", as in Pakistan there are many public organizations that have got privatized because of their inefficiency and losses such as Pakistan Telecommunication Company Limited (PTCL) and Karachi Electric Supply Company (Hereafter K.E.S.C.). Through this research, the changes in employees' performance after privatization were investigated. In Pakistan, this kind of study has rarely been carried out.

\footnotetext{
*Lecturer, Department of Management Sciences, University of Turbat, Turbat, Pakistan. Email: malikdad.baloch@gmail.com (Corresponding Author)
} 
The term privatization is being used nowadays to a great extent. Debates and discussions are going on in the country for and against of privatization of public organizations. The reason behind the privatization is to bring efficiency and effectiveness in the management of organizations to gain profitability and to adapt to the increasing competition in the tough market.

Privatization is not a new concept in Pakistan. It is backed in the 50s when Pakistan Industrial Development Corporation was established in 1952 to bring improvement in the industrial development of the country. In the decade of 1970, the nationalization occurred in a large number but it was reversed in 1977 . In the late 80 s, the privatization process was done on a large scale. After that, it was in 1991 that this process became effective. The entire process of privatization was made more transparent and effective on 22nd January 1991 when Privatization Commission was established. In the power sector, the major goals of privatization are two. The first goal is to capitalize on good management and bring new investments which are necessary to ensure the supply of electricity is more reliable for now and future. The other factor is to bring down the losses incurred by the government organizations and bring better management from the investors to reduce the losses and corruption.

Karachi is one of the top ten most populous cities in the world with 18 million inhabitants. It is the financial and economic hub of the country and hence the need for power and energy is apparent. Therefore, an efficient and well-managed energy-producing organization that could support the activities of the biggest city of Pakistan is the need of time especially in the present situation when the country is facing the most difficult times in its history. Karachi Electric Supply Company (hereafter K.E.S.C.) is a power generating and utility company that is serving around 2.3 million consumers of Karachi. It has around 17000 employees. K.E.S.C. came into being in 1913 under the "Indian Companies Act of 1882". It was made a public organization in 1952. K.E.S.C. is among the largest companies of Pakistan which are listed on all three of Pakistan's stock exchanges: Karachi Stock Exchange, Lahore Stock Exchange, and Islamabad Stock Exchange.

For more than one or two decades, the power sector in Pakistan is facing a financial crisis and is performing poorly and hence incurring lots of financial losses and is not capable to fulfill the demand of the biggest city of the country. The reasons behind the weak performance are weak governance, political interference, poor staff morale and employee performance, and disregard for good business practices. Sensing the bad history of operational and technical inefficiencies, mismanagement, and political interference, the Government recognized the urgent need to restructure the power. Finally, after a long period of debates and considerations government decided against privatizing the company on 29th November 2005. In September 2008, it came under the new management of Abraaj Capital. This company has come up with a significant number of experienced professionals and skilled managers who have been running the utility and other large companies for a long time.

The purpose of Human Resources is to measure and take necessary actions to improve the contribution made by the people to the organizations. Most of the organizations improve themselves by being more effective in terms of their policies implementations and efficient in terms of their use of resources. Effective here means to produce the right good or service that society believes suitable. Efficient means that it must use the minimum amount of resources needed to produce its goods and services. The result for society is an improvement in this industry's productivity which is the ratio of an organization's output (goods and services) to its inputs (people, capital, materials, and energy). 
Through productivity gains, managers can reduce costs, save scarce resources, and enhance profits. In turn, improved profits allow an organization to provide better pay, benefits, and working conditions. The result can be a higher quality of work-life for the employees, who are more likely to be motivated toward further productivity improvements.

The HR actions contribute to improved productivity directly by finding better and more efficient ways to meet objectives and indirectly by improving the quality of work-life for employees. Admittedly, managers must deal with trade-offs between employee satisfaction and economic, or bottom-line, results.

The importance of HR efforts comes from the realization that people are the common element in every organization; they create the strategies and innovations for which organizations are noted. As a slogan at a Union Carbide plant puts, "Assets make things possible, people make things happen." To carry out this role, managers and HR departments need to satisfy multiple and sometimes conflicting, objectives. Societal, organizational, functional, and personal objectives must be met, but only in a way that is appropriate to the organization being served. These objectives are achieved through a variety of HR activities designed to obtain, maintain, utilize, evaluate, and retain an effective workforce. These activities are the responsibility of all managers in the organization, even though many of them may be delegated to specialists in the HR department.

Within the HR department, one of the biggest factors of employee management is the performance management system. It is needed to know whether an organization can manage its human resources and talent effectively. Performance management provides information on who should be trained and in what areas, which employees should be rewarded, and what type of skills are lacking at the organization or unit level. Therefore, performance management also provides information on the types of employees that should be hired. When implemented well, performance management systems provide critical information that allows organizations to make sound decisions regarding their people resources (Aguinis, 2009).

There were many issues at K.E.S.C. before privatization such as lack of employee performance and productivity, inefficiency, unskilled employees, over-employed, non-punctuality, absenteeism. These issues are interrelated as they add up to grounds lack of performance. The other thing is the influence of politicians, government, and other pressure groups in public organizations. Hence there are lots of reasons which combine together to produce inefficiency and poor employee performance. The following questions have been investigated with this research:

- Effects of Privatization on the employee performance of K.E.S.C.

- Does loyalty of employees increase after privatization?

- Are employees more productive after privatization?

- Does privatization lead to better performance of employees and thus, organizational success?

- Does privatization increase effectiveness and efficiency at K.E.S.C?

The main objective of the study was to identify and analyze the impacts of the privatization of K.E.S.C. on the performance of its employees. Following are the objectives of the research: 
- To find out whether the privatization of K.E.S.C. has a positive effect on the overall performance of the employees.

- To analyze the relationship between privatization and employee performance.

- To determine that after privatization what changes occur in terms of employee performance?

- To find out whether employees' performance is more in privatized organizations or public organizations.

- To find out the effect of privatization on the overall success of an organization.

The research consists of the effects of privatization on the performance of K.E.S.C.'s employees. This study has investigated whether privatization has any significant effect on the employees' performance and they are more productive now when KESC is a privatized firm or were working better previously when it was a public organization. The research has further explored the reasons behind the better performance and productivity of employees in privatized or privately-owned organizations.

Following are the implications of this study which could be advantageous and would have a great impact on the understanding and development of the employees' performance in both, public and private organizations.

- The results of this study can play a very significant role in understanding the performance dimensions of the employees.

- To know the causes behind the better performance of the employees who are working in private organizations.

- The research has depicted the differences between the employees' working and performance in public and private organizations.

- It will facilitate the beneficiaries who are academia and professionals to diagnose and analyze the effects and implications of privatization on the employees and overall firms' performance. This study was carried out because, in Pakistan's history, many of the public companies have shown profits after getting privatized like Pakistan Telecommunication Company Limited and K.E.S.C. It means that public companies have the potential to make profits but there is a lack of employee performance which can be found through this research. The result of this study has shown the difference between good and bad performance of the employees. After the result, recommended changes that will help to increase employee performance were suggested.

As it has been found that this kind of research has not been taken place before which could be useful to know the effects of privatization on the employees' performance, it was a good start to investigate this issue. Employee performance is one of the touchstones to know and predict the overall performance of the organization; hence there should have been researching that could depict the real picture of the organization in some way.

\section{LITERATURE REVIEW}

There has been enough amount of data available about the performance of employees after privatization and many theories and models also exist. The variables that were used in this research 
have already been used by different other research studies and models, but in this study, they have been used in a different theoretical framework in order to keep this research valid and reliable.

\section{Communication}

After reviewing relative literature about the research problem, it has been found that there is a number of variables that affect the performance of employees positively or negatively after privatization. Communication from new management is one of the important factors which plays role in putting employees at ease or in trouble in a company where new management has taken over. If new management does not communicate adequately to the employees then it can set employees to speculate about the different transactions taking place in the organization.

"Leaders of an organization who keep everything inside or cannot communicate a message leave the individual to their devices to try and figure out what they may, or may not want. This is a failure of leadership and communication". Minimal communication from the new management can lead to a drop in productivity, employee morale, and job satisfaction. Communication can be done through verbal or nonverbal ways. "A supervisor who practices nonverbal immediacy has an increased interpersonal involvement with his/her subordinate". Good management can communicate to the employees by holding many meetings and providing frequent communication with employees in order to explain the new processes and changes that are taking place and make employees feel that they are part of this change.

\section{H1: To prove that internal communication in K.E.S.C. has increased after privatization.}

\section{Commitment}

The relationship between employee and organizational commitment and job performance is evident from the research done on this topic. In their study about career commitment and performance, effectiveness is of the view that there is a positive relationship between them. As found out low commitment during a job leads to a higher rate of turnover. A higher level of job satisfaction through job security leads to higher organizational commitment and that in return leads to enhanced employee performance.

To improve employee and organizational performance, the commitment of employees could be a significant tool. In the organizations where the stress level is high that is a cause of low satisfaction, leads to low organizational commitment. A high level of communication leads to a high level of commitment in organizations and that increases performance (Chen et al., 2005). One of the researches conducted by Chughtai and Zafar (2006), about the teachers in Pakistani universities led to evidence that teachers whose commitment were high outperformed, uncommitted teachers. The research found that there is a positive relationship between organizational commitment and employee job performance. Furthermore, they revealed that the variables such as education, sex, job status, age, and tenure had a positive and negative relationship with organizational commitment.

Shore et al. (1995) researched multinational firms in the United States in which they collected data of 231 managers and 339 subordinates and found that there is a positive correlation between job performance and commitment. In a study of 202 managers in different Malaysian companies, 
organizational commitment and corporate culture are interrelated and they both keep a significant level of impacts on employee performance.

H2: To prove that the loyalty of employees has increased after privatization.

\section{Training and Development}

Training has been defined as the systematic method which affects the knowledge, skills, and attitudes of individuals so that the effectiveness of the individuals, team, and organization improve. He further explains in his article about development as efforts that are systematically affecting the knowledge or skills of individuals for the sake of personal growth for future jobs and roles. Training objectives are the provision of skills, knowledge, and aptitude which are essential for doing the required job effectively and efficiently so that if he has the capacities, then he will progress, gain work efficiency, and the waste of machine-hours. The main objective of the training and development is to improve the performance level of the employees and bring effectiveness and efficiency to the organization.

Among other researchers who have proved the objectives of the training and development are Akintayo (1996), who viewed training and development as a tool to increase productivity, improve skills, knowledge, understanding, and attitude. It can enhance the utilization of the machine and can eliminate waste, accidents, absenteeism, and turnover. It will improve the work quality and increase the performance of the employees. It can initiate a program for manpower development and ensure the growth of the personnel and the organization.

Wrote in their research that "high-intensity trainers had a higher proportion of fast growers than low-intensity trainers". In the organization, it is necessary to have expert trainers who can train their employees effectively and it will help the company to improve its bottom line. An unprofessional trainer can waste the budget of the company which is allocated to its training and development for the employees because he will not be able to give the best training to employees hence not improving any productivity nor sharpening their skills.

H3: To prove that training opportunities have augmented after privatization.

\section{Financial Incentives}

One of the biggest factors of employee performance is motivation to work and perform. They should have a motive to work and outperform. Those employees who are more motivated, perform better than those who are not motivated and satisfied. McConnell and Rutherford (2005) opine "that different factors are very important for better performance of any company and effective and efficient organization depend upon the employees' motivation. To be motivated there must be a fair reward system in the organization. Reward systems can be defined as "formal or informal program used to recognize individual employee's achievements, such as accomplishment of goal or project." They could be non-financial such as promotion, work condition, etc., and can be financial such as salary, pension, bonuses, commission, etc. The aim of the workers to do a job in an organization is to offer his/her services, and earn money by applying the skills and knowledge he has learned, the experience he has gained in his life. Hence salary is the first incentive of the employee to work and perform his 
job. He will not work for a company that pays him nothing. Although he may get other benefits and non-financial incentives and rewards but failing to get pay or salary will not make him do the job. His satisfaction depends on the salary he gets to take home and fulfill his needs.

Salary or payment factor has a high effect on employee satisfaction. There is also a positive correlation between motivation, satisfaction, and reward. Maslow (1943) states that there are five levels of needs for employees to fulfill and the human needs were in the form of a hierarchy ascending from the lowest to the highest namely, physiological needs, safety needs, social needs, esteem needs, need for self-actualization. Good pay and interesting work are keys to higher motivation. According to research conducted on the banking sector of Pakistan, a Good salary has the biggest impact on employee motivation and hence on better employee performance. The employees are highly satisfied through increased and better salaries, as they can satisfy their other needs through this. They can improve their standard of living through good pay. Ali and Ahmed (2009), says that salary or payment factor highly influence employee satisfaction.

\section{H4: To prove that better financial incentives lead to better performance.}

\section{Job Security}

According to Meltz(1989), job security is "an individual remains employed with the same organization with no diminution of seniority, pay, pension rights, etc". Likewise, job security is depicted by (Herzberg, 1968) as the level of organizational provision of stable jobs to their employees and he urges the critical role of job security in influencing the job-related results because of this factor. For instance, it's a critical element in the health of employees psychological well-being of workers (Burke, 1991; Jacobson, 1987; Kuhnert \& Palmer, 1991), for employee retention and employee turnover (Arnold \& Feldman, 1982) and satisfaction in the job. An economic downturn often leads to higher unemployment rates, which increase employees' concerns about losing their jobs. Employees also may be less productive if company cutbacks brought on by the sagging economy prevented them from getting pay raises or bonuses.

\section{H5: To prove that job insecurity has increased in K.E.S.C. after privatization.}

\section{Organizational Change}

"In the dynamic world today, change in the workplace is a crucial topic, because change is seen primarily as an adaptive response by the system, acting as a whole or through subsystems with specific functions, to maintain itself in balance with a shifting environment".

There are different types of changes in the organization according to the nature and speed of occurrences. Different types of changes; radical, incremental, episodic, revolutionary and situated. Each needs a different kind of strategy and tactics to deal with. Transactional, transitional and transformational are three different types of changes that take place in any organization. Where minor changes are taking place is called transactional changes, e.g. giving new training to employees or changing the compensation system, switching software. Changes in roles/responsibilities, power bases, and systems are known as transitional changes. Opening a new plant in other vicinities is an example of transitional change, where more detailed planning and expertise are needed. While on the

Page no. 103 
other extreme transformational changes are those where it is needed to redesign the entire organization, even in includes changing the fundamental beliefs and norms of the organization, so that company can compete in the local as well as global market.

According to Susanto (2008)., "Management support can also be reflected from how change is accommodated by management through realignment of performance evaluation and employee compensation with change initiative program." Although the change occurs in all the areas of an organization, the focus and scope of this research are changing in employee performance. It is the people who are the real source of, and the vehicle for, change because they are the ones who will either embrace or resist change. If the people resist change, then all the efforts of the company vanish without any positive results. Hence it is the focus of this study to know what changes have occurred in terms of employee performance in the privatized energy company (K.E.S.C.) and whether the employee performance has increased after privatization? For this purpose, a research framework has been designed to measure the employee performance of K.E.S.C. after privatization.

H6: To prove that technological advancement has increased efficiency in K.E.S.C.

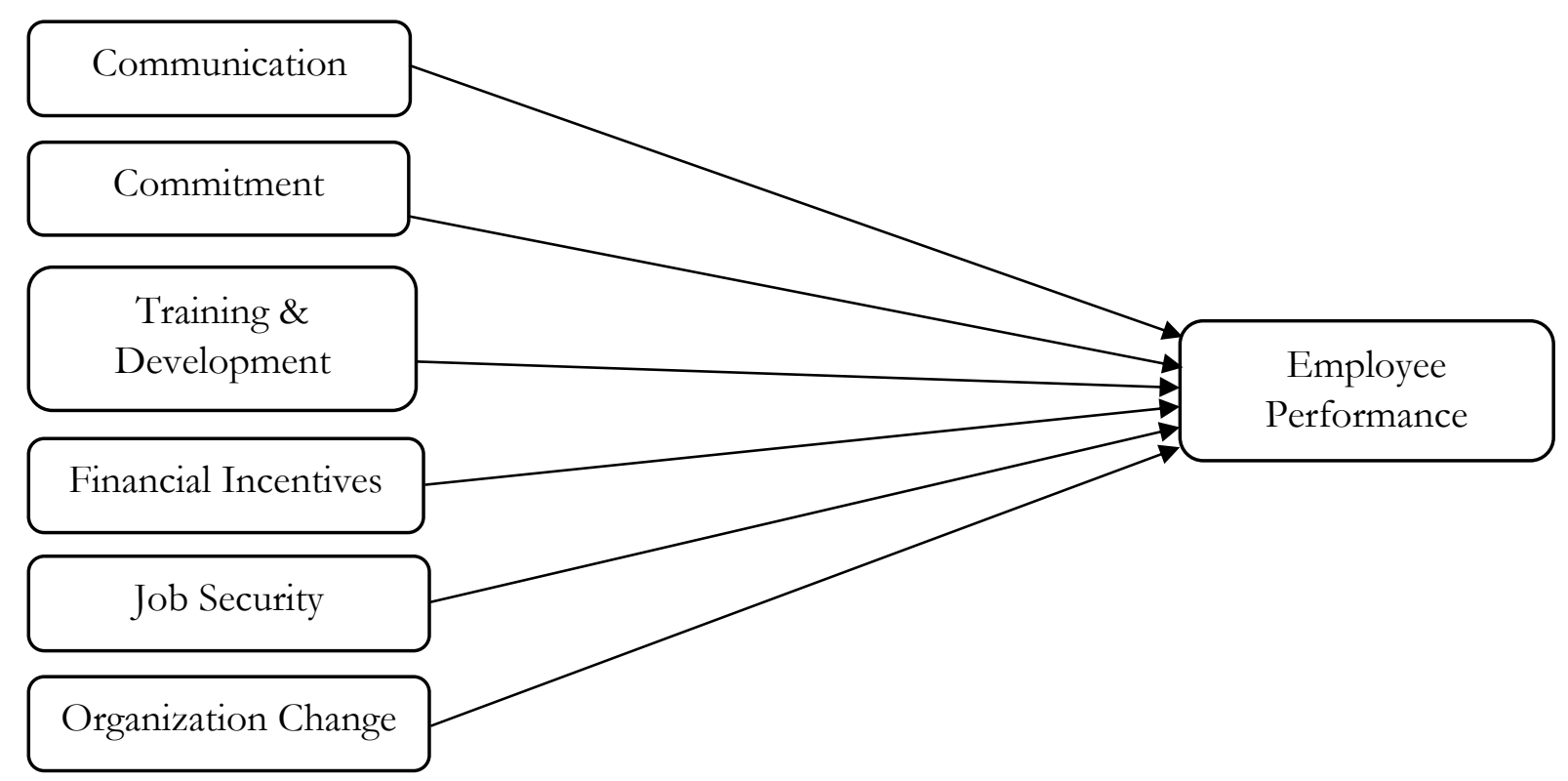

Figure 1: Theoretical Framework

\section{RESEARCH METHODOLOGY}

The research is quantitative descriptive research and to some extent qualitative as well. Hence, for collecting primary data, questionnaire and interview methods were used. First secondary data from the library, journals, books, internet, and other literature were consulted and then primary data was collected through questionnaires and interviews by the employees of K.E.S.C. The frame of reference includes both males and females who are employed on management cadre from middle management to upper management. Convenient sampling, most employees especially upper management don't have time to give interviews or fill up the questionnaires so a suitable strategy was made for it to 
distribute and collect questionnaires and conduct interviews. The survey and questionnaires were used and primary, secondary, and tertiary data were collected and used in this research. SPSS (Statistical Package for the Social Sciences) and Microsoft Excel were used to input the data and analyze the results. Microsoft Word was used for reporting the results and other data.

\section{ANALYSIS AND FINDINGS}

Communication is one of the important factors to increase the performance of the employees in any organization. This study by interviews gets to know that the communication level has increased in the company after privatization. Earlier it used to be so much humor roaming around the company but now every big decision made by the company is communicated to each employee down the level by email or in the shape of policies.

From the evidence of the questionnaire from the employees the employees are very satisfied that after privatization policies, goals and expectation are communication to them because before the privatization there were no properly objective, goals and expectation and yet it was there but it was not properly communicated to the employees which therefore created the environment of uncertainty but after the privatization the goals are properly communicated to the employees which shows the importance of the employees because when the goals, objective and expectation are properly communicated to the employees then the employees are satisfied with their work and they know that the organization are caring of the because when the goals and expectation is not communicated to the employees then the employees is not knowing the future plans, goals and objectives then there is the uncertainty environment and no one knows the future plans of the company the above table shows the evidence that only $2 \%$ of the employees are strongly disagree and saying that the goals and expectation are not adequately communicated to them and 4\% employees disagree about it while 10\% employees think that communication factor has not changed after privatization. $50 \%$ of employees are agreed and $33 \%$ of employees strongly agree that after privatization the goals and expectations are adequately communicated to them which shows a healthy sign of positivity. Hence after privatization, $80 \%$ of the employees are satisfied that the goals, objectives are fully communicated to them.

The communication of goals and expectations to the employees is very important because if the employees of the organization do know the goals then how come their performance will be improved because when the employees think that the organization is not feeling their importance and does not communicate the goals and expect the employees are not working up to their competency level and not their skills that they have, so the communication of goals expectation is very important as this could be the one main element of the enhancing performance and if the performance is not up to the standard the organization will not retain that employee for a long time and will fire that employee. So for achieving a high level of performance, there should not be a communication gap between the employee and company because the communication gap will directly suffer the employee in terms of performance, so there should be no compromise on the communication level because many of the top companies in Pakistan and as well as in global the communication between the employees and the company standards is very high and the top companies set high standards on communication because they know the importance of communication of goals and expectation and 
also knows the negative impact of communication gap on the employee and as well as on the success of the company.

From the evidence of the questionnaire and interview conducted the sayings of the employees of K.E.S.C. are agree that after privatization the employees have freedom of sharing their ideas to the upper management, before the privatization the upper management was solely authority and they do not even want to take the ideas from their lower management because they do not want to change the company. After all, ideas are for changes and innovation and the upper management didn't want to take ideas for any changes from their lower management. But after the privatization, the employees feel free to share their thinking and innovative ideas with their upper management and the upper management take serious note of their ideas because taking ideas from the lower management is fruitful because the lower management knows the difficulties faced by them and they share the solution and ideas to the upper management and in that way the upper management knows the condition of the company and it helped them in making big decisions.

The above table shows that $8 \%$ of the employees are strongly disagreed that there are opportunities to express their ideas to upper management, $15 \%$ of employees disagree about the verdict that opportunities are available for them to express their ideas to the upper management, $22 \%$ of employees are neutral and the rest of the $55 \%$ of the employees are positive about the verdict that there are opportunities available to them for sharing their ideas to the upper management, so it is evident from this study that the more number employees are satisfied that the opportunities are there to share the ideas to the upper management.

From the evidence for the questionnaire and interview conducted it has been observed that after privatization sharing of information is widespread and sharing and access to the information is widely shared so those who make the decision can make it easier. Before privatization, access to information was at a very low level so those who wanted to decide were unable to make it, after privatization the sharing of information is high.

The above table shows that $9 \%$ of employees are strongly disagreed about the verdict, but most of the employees were satisfied with the access of information, this is one of the important issues because when the access of information is there then there are more chances of making good decisions. So, decision power is increasing, when employees have the freedom to the decision power than their performance increases.

\section{Organizational Change}

This is obvious that after privatization there must be so many variations that have taken place in K.E.S.C. as far as their organizational change is concerned. Organizational change asserts influence on employees' performance positively as well as negatively.

The evidence taken from the questionnaire and interview conducted, observed that the high numbers of employees were satisfied that after privatization there has been technological advancement made and many new innovative technologies have been implemented because of that huge number of new projects has been started.

From the interviews this research gets to know that the K.E.S.C. is changing towards the customer-oriented company, they have come up with the concept of customer care department which 
is known as IBC stands for Integrated Business Centers. IBCs are one window solution for the customers for any type of billing complaint. Earlier they used to have Oracle software for the maintaining of data and solving customer complaints but now K.E.S.C. has implemented S.A.P business solution software which is one of the most expensive software and today in Pakistan only 20 companies have it out of them only 2 utility companies own it, one of them is K.E.S.C.

After privatization, technological advancement has made K.E.S.C. more efficient. The above table shows that $0 \%$ of employees strongly disagree and only $2 \%$ of the employees have disagreed about the technological development after privatization in K.E.S.C. From the above table, it has been clear evidence that $92 \%$ percent of the employees are satisfied with the technological development after privatization in K.E.S.C. the introduction of SAP and Automated Meter Reading (AMR) which has increased the efficiency level of the company and now the work which used to take lots of days earlier is now taking just a few hours. And now consumer issues are resolving quickly which is a very good sign for the consumer as well as for the company. The company wants to implement such new technological advancements to increase the efficiency level of the company.

Table 1: $Q 2 * D S G$ Cross tabulation

\begin{tabular}{|c|c|c|c|c|c|c|}
\hline & & \multicolumn{5}{|l|}{ Designation } \\
\hline & & $\begin{array}{l}\text { Less than } \\
\text { Assistant } \\
\text { Manager }\end{array}$ & $\begin{array}{l}\text { Assistant } \\
\text { Manager }\end{array}$ & Manager & $\begin{array}{l}\text { Deputy } \\
\text { General } \\
\text { Manager }\end{array}$ & $\begin{array}{l}\text { General } \\
\text { Manager } \\
\text { \& Above }\end{array}$ \\
\hline \multirow{5}{*}{$\begin{array}{l}\text { Management is very strict } \\
\text { about their objectives and } \\
\text { their deadlines. }\end{array}$} & Strongly Disagree & 1 & 0 & 0 & 0 & 0 \\
\hline & Disagree & 2 & 0 & 0 & 0 & 0 \\
\hline & Neutral & 2 & 0 & 0 & 0 & 0 \\
\hline & Agree & 22 & 8 & 5 & 1 & 0 \\
\hline & Strongly Agree & 22 & 13 & 15 & 7 & 2 \\
\hline Total & & 49 & 21 & 20 & 8 & 2 \\
\hline
\end{tabular}

From the evidence from the questionnaire and the conducted interviews, it has been observed that after the privatization in K.E.S.C. the management is working purely on merit and does not compromise on non-compliance and the management is strict about their goals, objectives and their deadlines. The management is at zero tolerance rates on their objectives and their deadlines, when management assigns any work then they want it to be done within the time frame. So the deadline is a must and the management is hoping that the tasks should be done before the deadlines and no compromise on late submission. Before the privatization the government management was very lenient about their objectives and goals; no deadlines were given to employees so the employees were very relaxed in terms of task submission, but after the privatization, the scenario has changed and there are very strict rules and regulations. The above table is evidence that only $1 \%$ of employees strongly disagrees that management is strict about their objectives and their deadlines and this employee belongs to below assistant manager level. The management has set tough objectives and deadlines to achieve and the employees have to be on their maximum level of efficiency to achieve those objectives. 


\section{Financial Factor}

Financial factor is one of the major factors which have a direct influence on the performance of the employees. Usually, it is directly proportional to the performance, as the financial benefits of the employee increase it leads to an increase in motivation level which directly affects the performance of the employees.

As it is commonly viewed that private companies give more compensation than public organizations. This has also been revealed by this study that K.E.S.C. has augmented its compensation packages for its employees after privatization. It can be seen from the verdict of the 100 respondents of the study, over $43 \%$ strongly agree that the remuneration packages have augmented after privatization and $35 \%$ of the respondents agree with it while $15 \%$ of employees said remuneration packages have not changed a lot after privatization, they are the same as previously given in government era. Only $7 \%$ of employees who responded to this question of the questionnaire disagree with the statement that their remuneration has increased after privatization.

K.E.S.C. has implemented the Annual Performance Appraisal (APA) system started in 2010, which has drastically discriminated good performers from bad performers. 3rd APA was done in December 2012. This research shows that $30 \%$ of the employees strongly agree that there is a direct connection between their performance and their compensation and 37\% of them also agree with them. $11 \%$ remained neutral about this verdict while only $24 \%$ disagreed with the statement that their performance has a direct connection with their compensation.

In the last APA of 2011 K.E.S.C. appraised its 5,516 employees on the following bell curve.

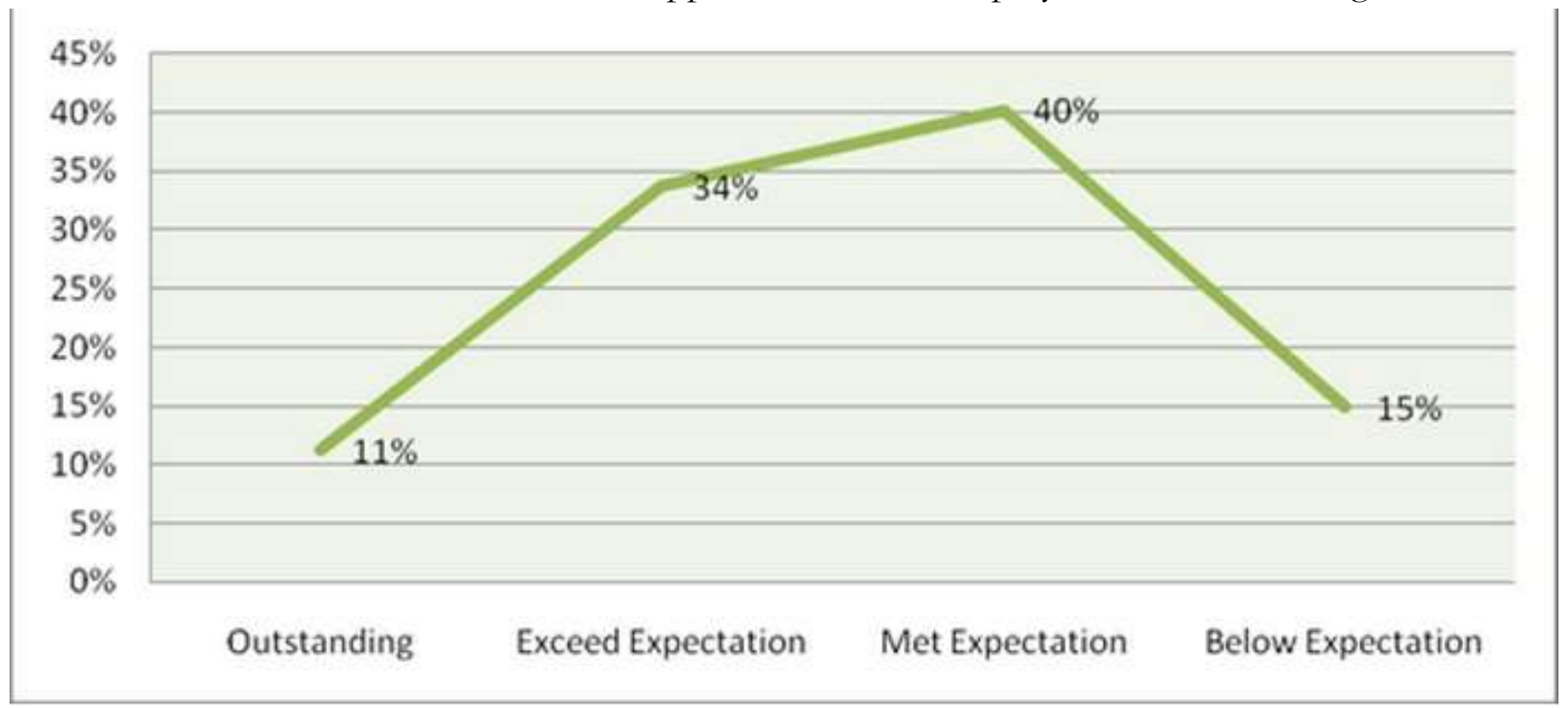

Figure 2: Bell Curve

Source: Taken from APA-2011 K.E.S.C. 
Notwithstanding the stretched financial position of the company, and the adverse economic environment of the energy sector that K.E.S.C. operates in, they are adhering to a robust "Salary Increment Matrix", effective 1st January 2012, as set out below.

\begin{tabular}{|lccccc|}
\hline Rating Scale & BE & ME & EE & Outstanding & Promotion \\
\hline Director & $0 \%$ & $6 \%$ & $10 \%$ & $16 \%$ & $6 \% *$ \\
\hline D'Dir, GM and DGM & $0 \%$ & $9 \%$ & $13 \%$ & $19 \%$ & $6 \% *$ \\
\hline Manager and Below & $0 \%$ & $13 \%$ & $18 \%$ & $24 \%$ & $6 \% *$ \\
$\begin{array}{l}\text { *extra promotion } \\
\text { reward }\end{array}$ & & & & & \\
\hline
\end{tabular}

Figure 3: Increment Matrix

*Source: Taken from APA-2011 K.E.S.C.

Furthermore, following a rigorous and established set of principles under the APA, a total of 308 management employees have been promoted as per the following matrix:

Table 2: Promotion Matrix

\begin{tabular}{ccc}
\hline Levels & Total & Percentage \\
\hline GM, D' Dir & 4 & $1 \%$ \\
DGM, Manager & 65 & $21 \%$ \\
D'Dr Asst Mgr \& Officer & 239 & $78 \%$ \\
Total & 308 & $100 \%$ \\
\hline
\end{tabular}

Source: Taken from APA-2011 K.E.S.C.

As per K.E.S.C. policy, a total of 101 management employees consistently rated "Below Expectation - BE" in the previous two or all three APA/PMS rounds are being exited from the organization on performance grounds. In addition, 666 management employees rated "BE" in the most recent APA 2011, or rated "BE" twice in the last three rounds, will be under close watch and given a fair chance to redeem themselves, or otherwise, in the next few months.

The outstanding performers get a $26 \%$ salary increment on their basic pay, employees meeting exceeds expectations get a salary increment of $16 \%$ on their basic pay, employees on meet expectation get only 10\% salary increment and employees below expectations do not get any increment in their salary. This means clearly that their performance is directly related to their compensation. This study has proved that the $79 \%$ of the employees agree with the statement that their compensation philosophy, policies, and procedures are communicated to them. While $9 \%$ of the respondents remain neutral and $12 \%$ disagree with the statement.

From the analysis of the interview, it has been known that their compensation or other financial variables are given to them from management are communicated to them, most of them are directly related to their targets, goals, and objectives of the department. Attaching financial incentives to the targets of the department has helped K.E.S.C.'s management a lot in achieving them. Because 
whenever they achieve their targets each member of the department gets the variable allowance in addition to their salary so everyone in the department is so desperate to achieve their departmental targets within a timeline.

Table 3: DSG * Q4 Cross tabulation

After privatization, there is a clear connection between my job performance and my compensation

\begin{tabular}{|c|c|c|c|c|c|c|}
\hline & & $\begin{array}{c}\text { Strongly } \\
\text { Disagree }\end{array}$ & Disagree & Neutral & Agree & $\begin{array}{c}\text { Strongly } \\
\text { Agree }\end{array}$ \\
\hline \multirow{5}{*}{ Designation } & Less than Assistant Manager & 4 & 6 & 7 & 19 & 13 \\
\hline & Assistant Manager & 0 & 2 & 1 & 9 & 9 \\
\hline & Manager & 2 & 6 & 1 & 4 & 7 \\
\hline & Deputy General Manager & 0 & 2 & 2 & 3 & 1 \\
\hline & General Manager \& Above & 0 & 0 & 0 & 2 & 0 \\
\hline Total & & 6 & 16 & 11 & 37 & 30 \\
\hline
\end{tabular}

From the above chart, it can be seen that $67 \%$ of the employees from a different cadre of the management agreement with the statement that there is a clear connection between their performance and their compensation. $11 \%$ of the employees remained neutral with the statement out of the $7 \%$ were below the assistant manager post. While on the other side $22 \%$ of the respondents from the different cadre of the management disagree with the statement that after privatization there is a clear connection between their job's performance and their compensation.

Table 4: EXP * Q4 Cross tabulation

After privatization, there is a clear connection between my job performance and my compensation

\begin{tabular}{ccccccc} 
& & $\begin{array}{c}\text { Strongly } \\
\text { Disagree }\end{array}$ & Disagree & Neutral & Agree & $\begin{array}{c}\text { Strongly } \\
\text { Agree }\end{array}$ \\
\hline \multirow{3}{*}{ Experience } & $5-10$ (Years) & 2 & 6 & 7 & 11 & 12 \\
& $11-13$ (Years) & 1 & 2 & 3 & 6 & 8 \\
& $14-18$ (Years) & 1 & 2 & 0 & 14 & 8 \\
Total & $19-25$ (Years) & 2 & 6 & 1 & 6 & 2 \\
& & 6 & 16 & 11 & 37 & 30 \\
\hline
\end{tabular}

About $8 \%$ of the respondents who disagree with the statement that there is a clear connection between their performance and their compensation have experience of more than 19 years in the K.E.S.C. Over $6 \%$ of the respondents disagree who has the experience of from 11 years to 18 years in K.E.S.C. $8 \%$ disagree whose experience is between 5 years to 10 years, making it total of $22 \%$ respondents who disagree with the statement that after privatization there is a clear connection between my job performance and my compensation. 
On the agreement side of the statement, $23 \%$ of respondents agree to have experience of 5 years to 10 years. $22 \%$ of the respondents agree to have experience of 14 years to 18 years. $14 \%$ of the respondents have experience in K.E.S.C. from 11 years to 13 years and $8 \%$ of the respondents have experience of more than 19 years in the K.E.S.C. making it total of $67 \%$ of respondents who agree with the statement that after privatization there is a clear connection between their job performance and their compensation. About $11 \%$ of the respondents remained neutral about the verdict of this statement.

Table 5: $D S G *{ }^{*} 7$ Cross tabulation

\begin{tabular}{|c|c|c|c|c|c|c|}
\hline \multicolumn{7}{|c|}{ The remuneration package has amplified after privatization. } \\
\hline & & $\begin{array}{l}\text { Strongly } \\
\text { Disagree }\end{array}$ & Disagree & Neutral & Agree & $\begin{array}{c}\text { Strongly } \\
\text { Agree }\end{array}$ \\
\hline \multirow{5}{*}{ Designation } & Less than Assistant Manager & 4 & 3 & 2 & 22 & 18 \\
\hline & Assistant Manager & 0 & 0 & 7 & 5 & 9 \\
\hline & Manager & 0 & 0 & 4 & 5 & 11 \\
\hline & Deputy General Manager & 0 & 0 & 1 & 3 & 4 \\
\hline & General Manager \& Above & 0 & 0 & 1 & 0 & 1 \\
\hline Total & & 4 & 3 & 15 & 35 & 43 \\
\hline
\end{tabular}

As it can be seen from the results of this study about $67 \%$ of the employees from the different cadre of the management agree with the statement that the remuneration package has augmented after privatization. Only $7 \%$ of the respondents below assistant manager level disagree with it that their salaries have increased after privatization while $11 \%$ of the respondents believe that there is no change in remuneration package after privatization.

Table 6: EXP * Q7 Cross tabulation

The remuneration package has amplified after privatization.

\begin{tabular}{ccccccc} 
& & $\begin{array}{c}\text { Strongly } \\
\text { Disagree }\end{array}$ & Disagree & Neutral & Agree $\begin{array}{c}\text { Strongly } \\
\text { Agree }\end{array}$ \\
\hline \multirow{3}{*}{ Experience } & $5-10$ (Years) & 3 & 1 & 5 & 15 & 14 \\
& $11-13$ (Years) & 1 & 2 & 4 & 9 & 4 \\
Total & $14-18$ (Years) & 0 & 0 & 6 & 6 & 13 \\
& $19-25$ (Years) & 0 & 0 & 0 & 5 & 12 \\
& & 4 & 3 & 15 & 35 & 43 \\
\hline
\end{tabular}

From the above chart, it is depicted that most of the employees differentiated by their experiences are agree with the statement that remuneration packages have augmented after privatization while only $7 \%$ of the respondents disagree with the statement.

Table 7: DSG * 99 Cross tabulation

After privatization K.E.S.C.'s compensation philosophy, policies and procedures are communicated to its employees.

\begin{tabular}{cccc}
$\begin{array}{c}\text { Strongly } \\
\text { Disagree }\end{array}$ & Disagree Neutral Agree & $\begin{array}{c}\text { Strongly } \\
\text { Agree }\end{array}$ \\
\hline
\end{tabular}




\begin{tabular}{|c|c|c|c|c|c|c|}
\hline \multirow{5}{*}{ Designation } & Less than Assistant Manager & 6 & 6 & 6 & 16 & 15 \\
\hline & Assistant Manager & 0 & 0 & 1 & 11 & 9 \\
\hline & Manager & 0 & 0 & 2 & 10 & 8 \\
\hline & Deputy General Manager & 0 & 0 & 0 & 5 & 3 \\
\hline & General Manager \& Above & 0 & 0 & 0 & 0 & 2 \\
\hline Total & & 6 & 6 & 9 & 42 & 37 \\
\hline
\end{tabular}

Only $12 \%$ of the employees less than the assistant manager level disagree with the statement that after privatization K.E.S.C.'s compensation philosophy, policies and procedures are communicated to them. $9 \%$ of the respondent from a different cadre of the management remained neutral and $79 \%$ of the employees from a different cadre of the management agreement with the statement that after privatization K.E.S.C.'s compensation philosophy, policies and procedures are communicated to them.

In the overall study from the questionnaires and interviews, the study depicts that the compensation packages of K.E.S.C. has increased after privatization but they have taken away so many other benefits from the employees which include their leave encashment, parents' free medical, no vehicle issued to employees only allowance given to them and earlier their leaves used to accommodate of the previous year but now they have only 30 days annual paid leaves either they avail it or not it's up to the employees. In the government period, they used to give free electricity units to their employee which is not the case now. The earlier government used to give medical facilities for the employees themselves, spouses, children, and parents. But after privatization medical facility is taken away for the parents of the employees.

This is all clear that financial incentives in terms of bonuses, allowances, variables have played a vital role in improving the performance of the employees of K.E.S.C.

\section{Training \& Development}

Training and development are important factors in improving the performance of the employees in any organization. The same is the case with K.E.S.C. after privatization. Following are the findings of the study. $15 \%$ of the respondents of this study show the results that there is no change as far as training is concerned. They say that the company takes the same training as it used to before its privatization. But a majority of the respondents 37\% agree and 38\% strongly agree with the statement that there is an increase in the training opportunities for the employees after privatization. While only $10 \%$ disagree with it.

Table 8: $210 *$ DSG Cross tabulation

\begin{tabular}{|c|c|c|c|c|c|c|}
\hline \multicolumn{7}{|c|}{ Designation } \\
\hline & & $\begin{array}{l}\text { Less } \\
\text { than } \\
\text { Assistant } \\
\text { Manager }\end{array}$ & $\begin{array}{l}\text { Assistant } \\
\text { Manager }\end{array}$ & Manager & $\begin{array}{l}\text { Deputy } \\
\text { General } \\
\text { Manager }\end{array}$ & $\begin{array}{l}\text { General } \\
\text { Manager } \\
\text { \& Above }\end{array}$ \\
\hline \multirow{5}{*}{$\begin{array}{l}\text { K.E.S.C. offers more training opportunities } \\
\text { for its employees as compared to before its } \\
\text { privatization. }\end{array}$} & Strongly Disagree & 7 & 1 & 0 & 0 & 0 \\
\hline & Disagree & 1 & 0 & 0 & 1 & 0 \\
\hline & Neutral & 12 & 1 & 2 & 0 & 0 \\
\hline & Agree & 17 & 10 & 6 & 4 & 0 \\
\hline & Strongly Agree & 12 & 9 & 12 & 3 & 2 \\
\hline
\end{tabular}


When the analysis of the same statement with the employees from a different cadre of the management was made, it is deduced that $8 \%$ of the employees who disagree with the statement are below the level of assistant manager and only 1\% assistant manager $1 \%$ of deputy general manager disagree with the statement that there are more training opportunities for employees now than previous; making it a total of $10 \%$ respondents disagree. While $15 \%$ responded neutral and a major chunk of the respondents of about $73 \%$ agrees with the statement.

If a comparison is done with the same statement of training opportunities increment after privatization with the employee's response compare to their experiences in the company, it can be taken that $10 \%$ of the employees disagree with it those have experience from 5 years to 13 years in the company. It means employees with more than 13 years of experience have been given many training opportunities in their time in K.E.S.C. $75 \%$ of the respondents agree with the statement and $15 \%$ remained neutral about the statement.

From the interviews with senior employees of K.E.S.C., it is known that earlier, only those employees were sent to training that has sourced from the politicians or labor unions, and most of the time training was only conducted in the documents not in real. But now the trend has changed; employees are sent to training on a need basis and recommended by their supervisor, and the training is properly evaluated after completion.

\section{Job Security}

One of the major issues which are being found in almost every employee of the K.E.S.C. is the insecurity of their jobs. Following is the analysis of the data regarding this issue. From the evidence of the questionnaire and interview conducted the perceptions of the employees of K.E.S.C. are negative in terms of job security.

The above chart shows that approximately $60 \%$ of the employees out of a sample size of 100 employees disagree that there is job security after privatization, $34 \%$ employees out of the sample size of 100 are neutral about this issue this is all because they were scared to answer this question honestly because of their job security so they answered Neutral instead of Strongly Disagree or Agree. And this is one of the major issues of K.E.S.C. after privatization which employees are facing at the moment. The respondents view that they have insecure jobs, but are pretending to be neutral. They fear that they may lose their jobs when their opinion is disclosed to the management of their company. There are only 6 respondents who view that their job is secure which could be because of their loyalty to the company. Before privatization, like in all government sector organizations, the employees were more satisfied regarding job security. There is a feeling among the employees that there may be major layoffs in the company as they have experienced during the post-privatization era. From the interviews conducted, job security was mostly the common factor of concern for the employees. Employees of K.E.S.C. have anxiety about losing their job at any time of the year.

The other question which was asked to the respondents was what the employees expect in the next five years about their current jobs. The remarks from the employees were distributed in this issue as $40 \%$ percent of the respondents agree $21 \%$ of the strongly agrees that their job may be secured for 
the next five years period in this company. The other 39\% percent viewed that they disagree $19 \%$ of them strongly disagree and feel insecure about the job security in K.E.S.C. The remaining $20 \%$ of the respondents were indifferent about the issue. However, from the insights taken from the interviews conducted, these 20 percent had the perception of insecurity and frustration about their job in the future, and for the purpose of fear of disclosing information they remained silent on this issue. According to the respondents of the interviews, the feeling of job security issue was apparent. This sense of insecure jobs, the performance, loyalty, and commitment of employees have been affected. In some cases, according to the interviews, it has increased but mostly it has negatively affected the performance of the employees as they feel dissatisfied and frustrated about their job insecurity.

After the examination and analysis of the job issue factor compare to management cadre and designation of the employees, and cross-tabulation of the data, it was revealed that the job security issue is more of concern for lower-level managers as below the level of assistant manager and they feel more insecure about their jobs. The upper management feels that the employees of the K.E.S.C. have a sense of more job security regarding their jobs. From the questionnaire data as depicted in the data of the above table, $30 \%$ of responses that hold less than assistant manager position is going against the job security and only $1 \%$ response is agreed upon it. The response is going more favorable in the case of upper-level management about this issue and they feel that their job is secure.

Cross-tabulation of the issue of job security was performed against the experience or number of years employees spent in the company and concluded that the employees with less experience felt greater insecurity in their jobs than the employees with more experience. As depicted in the data, mostly the respondents are neutral about this matter as they are uncertain about the issue or fear that the results of this study may affect their jobs.

Looking at the variables of job security from the perspective of age of the employees shows that the younger employees in age feel more insecure about their jobs. The reason may be the situation that they have been working for the company in less time than the older colleagues. They have seen the layoffs in the past five years of the company so they are more frustrated about the job security and feel that if there will be further layoffs, and then they will be the potential targets of these layoffs. The data shows that the 33 respondents between the ages of 28 to 35 are of the view that they disagree that their job is secure. On the other side, only 3 respondents of the age of 28-35 years agree that their job is secured which is a very small number against the previous one. From the age above 35 years from 36-43 years, the respondents view disagreement but to a smaller extent than the age limit below 35. It was inferred that the issue is of more concern among the lower age limit or younger employees.

Table 9: $D S G *$ Q 16 Cross tabulation

\begin{tabular}{ccccccc}
\hline \multicolumn{2}{c}{ I expect to have my current job for at least another five years in K.E.S.C. } \\
& $\begin{array}{c}\text { Strongly } \\
\text { Disagree }\end{array}$ & Disagree & Neutral & Agree & $\begin{array}{c}\text { Strongly } \\
\text { Agree }\end{array}$ \\
\hline \multirow{3}{*}{ Designation } & Less than Assistant Manager & 8 & 8 & 7 & 13 & 13 \\
& Assistant Manager & 4 & 6 & 9 & 0 & 2 \\
& Manager & 5 & 5 & 3 & 4 & 3 \\
& Deputy General Manager & 2 & 1 & 1 & 3 & 1 \\
& General Manager \& Above & 0 & 0 & 0 & 0 & 2
\end{tabular}


Total

19

20

20

20

21

This data and graph show that in the next five years the response is distributed among the different designations from which some are of the view that they may be in the company for the next five years and some think that they may lose their current jobs in the future. Among the respondents, those whose designation is less than assistant manager feels more secure regarding job security for the next five years in the company. While the 10 assistant managers show agreement with the question.

Looking at the issue of job security for the coming five years at KESC, the respondents according to their experience in the company have also dispersed views and feelings. Among the respondents according to their period of stay and work in the company, those who have more experience in the company are to some extent more optimistic about their jobs in the future. This may be the cause of the new management's downsizing and efficiency policy. The respondents have experienced this during the past few years when there were layoffs in big chunks.

Looking at the issue of job security for the coming five years at KESC, the respondents according to their age have also dispersed views and feelings. Among the respondents according to their age limit, the older employees are more optimistic about their jobs in the future than those of younger employees. This could be the experience level of the senior employees or their loyalty to the company or some factor.

\section{Commitment and Loyalty}

Commitment and loyalty are hardly found in public organizations. This study has been conducted to see what has happened to the commitment factor of the employees after the privatization of K.E.S.C. and how it has affected their performance. The evidence taken from the questionnaire and interview conducted observed that the high numbers of employees are committed and loyal to the company after privatization. $49 \%$ percent of the respondents viewed that the commitment of employees and company towards each other has grown after privatization. From the interviews, it was observed that previously the commitment of the company and employees were lower.

This commitment from the company and its new management has made advancements and positive changes in the company and has increased the efficiency level of the company. The company has grown its image and its name to a great extent in the last 7 years. Previously, the employees did not feel proud to be a part of the company. Now the sense of loyalty and commitment with the company is increasing with the time passing by it is taking a positive change in the sense of pride and prestige in terms of belonging to this company. The changes which have occurred in the company had a great impact on the loyalty level of employees and which leads to higher performance.

According to the interviews, it was revealed that the company's commitment has increased in terms of company image and employees' morale building. K.E.S.C. does not compromise over its morality. Hence there is a big commitment from the side of K.E.S.C. towards the employees' loyalty. The company has inspired this attitude of commitment and loyalty to their employees to a great magnitude. As a result, the commitment level of the employees has increased therefore it has affected the performance level of the employees. From the evidence of the questionnaire and interview conducted it has been observed that over the past 5 years, employees' loyalty to the company has 
grown stronger. But in some cases, it is also shown that before privatization K.E.S.C. has so many committed and loyal people which are still the same after privatization.

The above table shows that $56 \%$ of the employees out of a sample size of 100 agree that about the above verdict, most of the employees' view that their loyalty has grown. The reason behind this increase may be the increased financial incentives which the new management is paying to its employees as inferred from the interviews conducted. The other reason could be the increased communication from the top to lower management and staff. The 31 responses as neutral can be inferred from the view of the management, during their interviews and the respondents of questionnaires that there is a big issue of job insecurity which has caused impacting negatively to the performance and the loyalty and commitment.

From the analysis through cross-tabulation of two factors, designation and the question of stronger loyalty, it is inferred that overall management believes that employee loyalty has increased over five years, but there is more agreement among the lower management in this issue. The data shows that the lower management believes that the employee loyalty to the company has increased as they can see it in the performance level of the employees which has increased significantly and through the interviews conducted, this opinion is overwhelming. Furthermore, the data shows some respondents were indifferent as there is a feeling of insecure jobs among the employees of lower management, which was evident from the discussion and interview with the management of the company.

From the analysis through cross-tabulation of factors, experience or the number of years employees working in the company, and the question of stronger loyalty, it is inferred that overall management believes that the employee loyalty has increased after privatization and this agreeing situation is more common in the staff who have spent less time in the company or their experience is lower. Through the examination of the issue of commitment, it is observed from the data that most of the employees feel proud to belong to this organization after privatization. The data regarding cross-tabulation of the issue with the designation of the management personnel shows that in the lower level of the management this phenomenon has increased to a greater extent than among the upper management after privatization. Although the respondents through the analysis in this angle show somewhat distributed, the majority of the data falls into the agree side of the question.

The data about the factors of commitment and experience through cross-tabulation shows that those employees who have more experience in the company feel more proud to belong to the organization after privatization. From the insights of the interviews, it was observed that this feeling of pride and commitment has increased because of more financial incentives to the experienced employees after privatization and a higher communication level in the management.

\section{CONCLUSION AND RECOMMENDATIONS}

After extensive research and examination of all the variables and factors, the study is led to believe that the employee performance at KESC has increased after privatization, as the majority of the respondents had a more positive opinion about the performance increase after privatization. The variables for this study leading to employee performance are given below: 
1. Commitment

2. Communication

3. Financial Incentives

4. Organizational Change

5. Training \& Development

6. Job security

The management of KESC revealed that it has been so many changes taken place in the company after privatization which made their performance better; employees were getting more financial incentives and the communication from top to bottom level of the organization has increased to a great extent, which has affected the performance of the employees positively. The correlation analysis shows that the commitment, communication, financial incentives and job security variables have a positive relationship with the overall performance of the employees.

According to this study, more than half of the respondents responded that they feel insecure in terms of their jobs as there have been big numbers of layoffs in the company after two years of privatization. Some of the respondents presented a neutral view in this matter because of the sensitivity of the issue that they demonstrate some fear of losing their jobs if this questionnaire may be presented to K.E.S.C. management they doubt. Due to a lack of job security, employees exhibit dissatisfaction on the job. This research has found that because of unclear policy on job security, there is high frustration among employees. It also has a negative impact on loyalty.

According to the respondents, after privatization, KESC is more committed in terms of organizational change and the company's image. The remuneration package of the employees has been increased drastically and the distribution of the incentives is based on recovery and achieving departmental targets and salary increment is purely based on the performance of the employees. PMS has been implemented in K.E.S.C. since 2010 and according to which those who will perform better will get more financial and other benefits. Performance appraisal has replaced seniority-based compensation. The study finds that the overall financial benefits and remuneration have been increased after privatization.

According to the majority of the respondents, technology has played a vital role in organizational change hence improving the performance of the company. Interviews analysis inhibits that the work environment at K.E.S.C. has also changed positively to some extent but in many areas of K.E.S.C. there is no any or minor organizational change has taken place, they are the same as it was in government time. As for as transparency is concerned; check and balance has increased drastically in the overall system which helped in reducing corruption and increasing the performance level of the employees.

From the questionnaire and interviews, this study found that the communication factor has improved to the great extent after privatization. Previously objectives and goals of the company were there but not sufficiently communicated to the employees. But now the targets, objectives, and policies of the company are communicated down the level and are achieved.

The research found that K.E.S.C. offers more training opportunities for its employees as compared to before its privatization. Earlier the training was scheduled but only those who could 
attend the training sessions those who have political affiliations and use references but now this practice is reduced. Another most important finding of the research from interviews shows that it was a great political and labor union influence before privatization which has reduced a lot. Earlier all the work of the company was done under the influence of labor union and their affiliation with political parties.

\section{The recommendations of the study}

The recommendations of the study are mentioned below:

a) There is a significant need to improve communication at all organizational levels. The employees should have the freedom to share their views and problems with their supervisors and top management. Apart from managements' actively encouraging the communication from top to lowerlevel staff, involvement of employees in the business decision making should be practiced so that employees could feel more motivated and present enthusiasm in the workplace.

b) Relevant efforts should be taken to make employees feel that their jobs are secure so that they can show their full commitment to the work.

c) A career development program should be started at both the upper and lower level of the organization, in order to inspire a clear vision about the employees' career goals and the future growth of the company in the mind of the employees, so that the employees could be more committed and loyal to the company and on the other hand they could be more satisfied regarding their job security. This eventually would motivate them to work for the company more efficiently and productively. It will enhance their enthusiasm when they realize its benefits and feel that the company is showing concern about them which will make them contribute effectively towards their personal and organizational goals.

d) Teamwork culture should be adopted in the whole hierarchy of the organizations' department. It will make synergy and open communication among the employees and they will have the opportunity to share their experiences and ideas with each other for their personal and organizational goals and objectives. The seniors and experienced employees will share their professional experiences and expertise with their junior colleagues and can learn new knowledge and innovative ideas from the junior employees. It will create strong professional relationships and commitment among the employees and as a result, it will produce a huge impact on both the operational and strategic objectives of the organization. However, one thing should be considered that the teamwork approach will have some impacts and changes in the performance management system (PMS), which should be altered and changes be adjusted in it. It should include both individual and team-based parameters of performance appraisal to produce productive results.

e) Steps should be taken to reduce the political influence to its highest extent so that professionalism can grow stronger in the company.

\section{REFERENCES}

Aguinis, H. (2009). Performance management (2nd ed.). Prentice-Hall/Pearson Education. 
Akintayo, M. O. (1996). Upgrading the teacher's status through in-services training by Distant Learning System"(DLS) Unpublished. A public lecturer at the Second convocation ceremony of NTI, NCE by DLS.

Ali, R., \& Ahmed, M. S. (2009). The impact of reward and recognition programs on employee's motivation and satisfaction: an empirical study. International review of business research papers, 5(4), 270-279

Arnold, H. J., \& Feldman, D. C. (1982). A multivariate analysis of the determinants of job turnover. Journal of applied psychology, 67(3), 350-60

Burke, P. J. (1991). Identity Processes and Social Stress. American Sociological Review, 56(6), 836-849.

Chughtai, A. \& Zafar, S, "Antecedents and Consequences of Organizational Commitment Among Pakistani University Teachers," Applied Human Research Management, 11(1), 39-64, 2006.

Chen, J. C., Silverthorne, C., \& Hung, J. Y. (2006). Organization communication, job stress, organizational commitment, and job performance of accounting professionals in Taiwan and America. Leadership \& organization Development journal, 27(4), 242-249.

Herzberg, F. (2008). One more time: How do you motivate employees?. Harvard Business Review Press.

Jacobson, D. (1987). A personological study of the job insecurity experience. Social behavior, 2(3), 143155.

Kuhnert, K. W., \& Palmer, D. R. (1991). Job security, health, and the intrinsic and extrinsic characteristics of work. Group \& Organization Studies, 16(2), 178-192.

Maslow, A. H. (1943). A theory of human motivation. Psychological Review, 50(4), 370-396

McConnell, J. P., \& Rutherford, D. G. (1990). Hotel reservations: The guest contract. The Cornell Hotel and Restaurant Administration Quarterly, 30(4), 61-65.

Meltz, N. M. (1989), Job security in Canada. Industrial Relations, 44(1), 149-161.

Shore, L. M., Barksdale, K., \& Shore, T. H. (1995). Managerial perceptions of employee commitment to the organization. Academy of Management Journal, 38(6), 1593-1615.

Susanto, A. B. (2008). Organizational readiness for change: A case study on change readiness in a manufacturing company in Indonesia. International Journal of Management Perspectives, 2(1), 5062. 